\title{
DISCUTINDO A RELAÇÃO ENTRE O PODER JUDICIÁRIO E OS TRIBUNAIS DE CONTAS
}

Coluna publicada em 12.12.2017: <https://www.conjur.com.br/2017-dez-12/ contas-vista-discutindo-relacao-entre-poder-judiciario-tribunais-contas $>$

O sistema de tripartição de Poderes adotado pelo Estado brasileiro não nos dá a exata dimensão de como funciona efetivamente a distribuição dos Poderes em nossa República. A organização estabelecida pela nossa Constituição, que prevê como Poderes independentes o Legislativo, o Executivo e o Judiciário (art. 2o) decorre de uma evolução em que muitas são as possibilidades oferecidas pelos vários e relevantes estudos de Teoria do Estado, que não é o caso de se aprofundar agora, mas evidencia o quão difícil e complexo é construir um modelo ideal de Estado e respectiva administração pública.

Essa organização e separação de Poderes não é absolutamente precisa nem uniforme pelo mundo, e a relação entre eles é diversificada, cada caso com suas peculiaridades e características próprias, estabelecendo várias formaçōes e diferenças de relacionamento entre si. Há desde as separações mais rígidas, como é o caso do Brasil, com garantias claras e formais de autonomia, até outras menos, como se vê nos regimes parlamentaristas.

E há órgãos e instituições independentes que sequer figuram nessa relação.

No Brasil, por exemplo, os tribunais de contas são dotados de garantias que lhes conferem autonomia, embora não integrem quaisquer dos Poderes referidos.

Em Portugal, há referência na Constituição não ao Poder Judiciário, mas aos tribunais, entre os quais se incluem os tribunais de contas como um tribunal especializado em matéria financeira.

Nos países de tradição anglo-saxã, nem existem tribunais de contas, e as funções de análise das contas públicas são cumpridas por órgãos não colegiados, os chamados "escritórios de auditoria". É o caso, para citar alguns exemplos, do U.S. 
Government Accountability Office (GAO), nos Estados Unidos, do National Audit Office (NAO), no Reino Unido, e, na Austrália, do Australian National Audit Office (ANAO).

Uma evidência das múltiplas diferenças nas formas de organização da administração pública e distribuição dos Poderes do Estado.

Outros órgãos também são dotados de elevado grau de autonomia, como se pode constatar, no Brasil, quanto ao Ministério Público e à Defensoria Pública.

Interessa particularmente para o Direito Financeiro a atuação dos tribunais de contas, tendo em vista sua direta relação com o controle da atividade financeira do Estado. ${ }^{1}$

E, no que se refere às finanças públicas, as relações de poder entre os órgãos que os exercem são sempre mais delicadas e exigem maior atenção.

Não é por outra razão que o orçamento público é a "lei materialmente mais importante do ordenamento jurídico logo abaixo da Constituição (...)", por ser "a que mais influencia o destino da coletividade".

Nesses casos, é importante a exata delimitação de competências, com a especificação das funções que cada um exerce, a fim de evitar conflitos entre os órgãos do Estado que exercem poderes no âmbito das finanças públicas.

No Brasil, os tribunais do Poder Judiciário e os tribunais de contas exercem funções essenciais e fundamentais para o funcionamento de nosso Estado Democrático de Direito, e a harmonia entre eles, preconizada logo no artigo $2^{\circ} \mathrm{da}$ Constituição, sempre deve prevalecer e há de ser um princípio a ser seguido à risca, sem o que todos saem prejudicados.

Trata-se de uma relação importantíssima no âmbito do Direito Financeiro, cujos detalhes exigem por vezes ajustes finos que pouco têm sido analisados e abordados e demandam um maior aprofundamento. Atritos e desgastes nessas relações não são bem-vindos.

1 Os tribunais de contas já foram por diversas vezes abordados nesta seção, e remeto os leitores às colunas Tribunais de contas são guardióes do dinheiro público, publicada em 14 de janeiro de 2014 e "PEC do padrão mínimo" vai aperfeiçoar tribunais de contas, publicada em 26 de julho de 2016. Ambas constam deste livro.

2 Conforme as bem lançadas palavras do ministro Carlos Ayres Britto durante o paradigmático julgamento da Ação Direta de Inconstitucionalidade 4.048, em 2008: "Abaixo da Constituição, não há lei mais importante para o país, porque a que mais influencia o destino da coletividade"; é a "lei materialmente mais importante do ordenamento jurídico logo abaixo da Constituição" (Min. Carlos Britto, STF, Tribunal Pleno, ADI 4.048-MC/DF, rel. Min. Gilmar Mendes, j. 14.5.2008). 
Mas a crescente importância das normas de Direito Financeiro, e o cada vez mais necessário respeito que se deve a elas, têm intensificado os aspectos controvertidos dessas relaçôes e os potenciais e efetivos pontos de atrito e conflito, que devem ser objeto de atenção, reflexão e rápida solução.

Chamei a atenção para algumas dessas questões há algum tempo, por ocasião das discussões acerca do impeachment da presidente recentemente afastada do cargo, em que descumprimentos das normas de Direito Financeiro deram origem a vários tipos de demandas, de várias naturezas, em órgãos diferentes, sujeitos a procedimentos distintos. Foi quando se pôde notar que uma operação de crédito ilegal pode caracterizar um crime comum, um ato de improbidade administrativa, uma infração administrativo-financeira e crime de responsabilidade. O que coloca em xeque a atuação simultânea do Poder Judiciário, do Tribunal de Contas da União e do Congresso Nacional. Com potencial, ainda sem solução satisfatória e definitiva, de resultarem em decisões contraditórias e conflitantes. ${ }^{3}$

Recentemente, intensificou-se o conflito entre o Poder Legislativo e os tribunais de contas no que tange ao julgamento das contas dos prefeitos. A decisão do Poder Judiciário (STF), nos RE 848.826 e 729.744, provocou polêmica ao atribuir às câmaras de vereadores a competência para o julgamento das referidas contas, mesmo quando se trata de contas de gestão, nas quais atuavam como ordenadores de despesas, caso em que tinham suas contas apreciadas e julgadas pelos tribunais de contas. Vê-se o Poder Judiciário interferindo para delimitar atribuiçôes no âmbito do controle externo. ${ }^{4}$

O Conselho Nacional de Justiça, desde sua criação, nunca teve bem delimitadas suas exatas atribuiçôes no que tange à sua função de exercer o "controle da atuação administrativa e financeira do Poder Judiciário" (Constituição, art. 103, $\$ 4^{\circ}$ ), sendo muitos os conflitos com a atuação dos tribunais de contas, a quem também compete a fiscalização financeira da administração pública e, por consequência, dos tribunais. Uma fonte de insegurança jurídica e relações conflituosas que está há tempos exigindo mais atenção.

É interessante notar que as relações entre os Poderes não são sempre conflituosas. Podem ser bastante harmônicas, como se deseja. Há, no entanto, situações em que se excede nessa "harmonia", tão intensa que deixa de ser republicana. É o que

3 Vide coluna Cuidado, pedalar pode dar cadeia!, publicada em 5 de maio de 2015 (e que consta neste livro).

4 Sobre o tema, veja-se coluna STF gera polêmica ao decidir sobre julgamento de contas de prefeitos, publicada em 23 de agosto de 2016 (e que consta neste livro). 
se vê por vezes nas indicações para a composição dos tribunais de contas, atribuição dos Poderes Legislativo e Executivo, que têm o péssimo hábito de não levar em consideração critérios constitucionais e meritocráticos, deixando prevalecer o compadrio, e o resultado são escolhas de membros que ficam devendo em termos de "competência".

Nos últimos tempos o Poder Judiciário passou a intervir duramente nessa relação, afastando do cargo e até mesmo levando à prisão conselheiros de tribunais de contas de vários estados por irregularidades cometidas. ${ }^{5}$ Curioso notar que as relações entre os Poderes ao mesmo tempo exageram na intimidade para em seguida terminarem em graves conflitos. Uma verdadeira relação de amor e ódio, nada simples de se explicar nem de entender.

Não são poucos os casos em que essa relação harmoniosa entre os Poderes envolve verdadeiras trocas de favores, "nepotismos cruzados", leniências recíprocas na fiscalização de irregularidades e tantas outras. Uma demonstração de que a harmonia precisa existir e estar presente, mas em termos republicanos! Nem toda harmonia é a adequada para o bem do Estado Democrático de Direito.

Igualmente indesejáveis são as relações desarmônicas e conflituosas, com interferências que ultrapassem os limites constitucionais.

Razões suficientes para que o Poder Judiciário e os tribunais de contas — bem como os demais poderes e órgãos independentes — "discutam a relação" e encontrem as soluções para uma convivência realmente harmônica, imprescindível para que o Estado brasileiro possa atingir seus objetivos fundamentais o quanto antes.

Uma discussão que não pode ser postergada, até porque se está diante de um verdadeiro "casamento" absolutamente indissolúvel, insuscetível de separação ou divórcio. Ou caso se prefira reconhecer uma "união estável", sendo inviável o rompimento do compromisso, é imprescindível que os termos do "contrato de convivência" sejam claros, precisos e transparentes, sem o que os conflitos se intensificarão, e os tapas vão se sobrepor aos beijos.

O final de ano está chegando, época oportuna para esquecer as diferenças, promover e celebrar a paz e a harmonia — entre as pessoas e os Poderes.

5 O tema foi abordado na coluna Moralização da administração pública: chegou a vez dos tribunais de contas, publicada em 4 de abril de 2017 (e que consta neste livro). 